\title{
Suppression of Type I Interferon Production by Human T-Cell Leukemia Virus Type 1 Oncoprotein Tax through Inhibition of IRF3 Phosphorylation
}

\author{
Chun-Kit Yuen, ${ }^{\mathbf{a}}$ Ching-Ping Chan, ${ }^{\mathbf{b}}$ Sin-Yee Fung, ${ }^{\mathbf{b}}$ Pei-Hui Wang, ${ }^{\mathbf{b}}$ Wan-Man Wong, ${ }^{\mathbf{a}}$ Hei-Man Vincent Tang, ${ }^{\mathbf{b}}$ Kit-San Yuen, $^{\mathbf{b}}$ \\ Chi-Ping Chan, ${ }^{\text {b }}$ (D) Dong-Yan Jin, ${ }^{\text {b }}$ Kin-Hang Kok ${ }^{\mathbf{a}}$ \\ Department of Microbiology, The University of Hong Kong, Pokfulam, Hong Kong ${ }^{a}$; School of Biomedical Sciences, The University of Hong Kong, Pokfulam, Hong Kong ${ }^{b}$
}

\section{ABSTRACT}

Infection with human T-cell leukemia virus type 1 (HTLV-1) is associated with adult T-cell leukemia (ATL) and tropical spastic paraparesis. Type I interferons (IFNs) are key effectors of the innate antiviral response, and IFN- $\alpha$ combined with the nucleoside reverse transcriptase inhibitor zidovudine is considered the standard first-line therapy for ATL. HTLV-1 oncoprotein Tax is known to suppress innate IFN production and response but the underlying mechanisms remain to be fully established. In this study, we report on the suppression of type I IFN production by HTLV-1 Tax through interaction with and inhibition of TBK1 kinase that phosphorylates IRF3. Induced transcription of IFN- $\beta$ was severely impaired in HTLV-1-transformed ATL cells and freshly infected T lymphocytes. The ability to suppress IRF3 activation was ascribed to Tax. The expression of Tax alone sufficiently repressed the induction of IFN production by RIG-I plus PACT, cGAMP synthase plus STING, TBK1, IKKE, IRF3, and IRF7, but not by IRF3-5D, a dominant-active phosphomimetic mutant. This suggests that Tax perturbs IFN production at the step of IRF3 phosphorylation. Tax mutants deficient for CREB or NF- $\kappa$ B activation were fully competent in the suppression of IFN production. Coimmunoprecipitation experiments confirmed the association of Tax with TBK1, IKKE, STING, and IRF3. In vitro kinase assay indicated an inhibitory effect of Tax on TBK1-mediated phosphorylation of IRF3. Taken together, our findings suggested a new mechanism by which HTLV-1 oncoprotein Tax circumvents the production of type I IFNs in infected cells. Our findings have implications in therapeutic intervention of ATL.

\section{IMPORTANCE}

Human T-cell leukemia virus type $1(\mathrm{HTLV}-1)$ is the cause of adult T-cell leukemia (ATL), an aggressive and fatal blood cancer, as well as another chronic disabling disease of the spinal cord. Treatments are unsatisfactory, and options are limited. A combination of antiviral cellular protein alpha interferon and zidovudine, which is an inhibitor of a viral enzyme called reverse transcriptase, has been recommended as the standard first-line therapy for ATL. Exactly how HTLV-1 interacts with the cellular machinery for interferon production and action is not well understood. Our work sheds light on the mechanism of action for the inhibition of interferon production by an HTLV-1 oncogenic protein called Tax. Our findings might help to improve interferonbased anti-HTLV-1 and anti-ATL therapy.

- ive to 20 million people worldwide are infected with human T-cell leukemia virus type 1 (HTLV-1), among them about 3\% might develop adult T-cell leukemia (ATL), and another $1 \%$ could suffer from tropical spastic paraparesis. Both diseases are poorly treatable $(1,2)$. A combination of alpha interferon (IFN- $\alpha$ ) and zidovudine has emerged as the standard first-line therapy for ATL $(3,4)$. Whereas zidovudine is a nucleoside analog that inhibits reverse transcriptase, IFN- $\alpha$ is an antiviral cytokine that serves as a key effector in innate immunity (5). Both IFN- $\alpha$ and zidovudine are required in this modality, but how they cooperate to achieve optimal therapeutic effect is not understood. To shed light on this, it will be of importance to elucidate how HTLV-1 perturbs type I IFN production and signaling.

Recognition of pathogen-associated molecular patterns by pattern recognition receptors of the host cell triggers innate immune response, including the production of type I IFNs $(6,7)$. For example, upon recognition of viral nucleic acids, Toll-like and RIG-I-like receptors, as well as other sensors, generate an activation signal that is transmitted through adaptor proteins such as MAVS and STING, resulting in TBK1-dependent phosphorylation of IRF3 and IRF7 transcription factors which translocate into the nucleus to activate IFN promoters $(8,9)$. Increased expression of type I IFNs ultimately leads to the activation of JAK-STAT signaling and the consequent induction of IFN-stimulated genes (ISGs), including those coding for some proinflammatory cytokines (10). Exactly how HTLV-1 infection is sensed by the host cell is poorly understood. The involvement of cytoplasmic RNA sensor RIG-I in the sensing of another retrovirus human immunodeficiency virus type 1 (HIV-1) has been suggested (11). Because optimal function of RIG-I requires PACT, a cellular double-

Received 20 January 2016 Accepted 24 January 2016 Accepted manuscript posted online 27 January 2016 Citation Yuen C-K, Chan C-P, Fung S-Y, Wang P-H, Wong W-M, Tang H-MV, Yuen K-S, Chan C-P, Jin D-Y, Kok K-H. 2016. Suppression of type I interferon production by human T-cell leukemia virus type 1 oncoprotein Tax through inhibition of IRF3 phosphorylation. J Virol 90:3902-3912. doi:10.1128/JVI.00129-16.

Editor: F. Kirchhoff

Address correspondence to Dong-Yan Jin, dyjin@hku.hk, or

Kin-Hang Kok, khkok@hku.hk.

Copyright $\odot$ 2016, American Society for Microbiology. All Rights Reserved. 
stranded RNA-binding protein which binds and activates RIG-I (12), it will be of interest to see whether PACT might also play an important role in the sensing of HIV-1 and HTLV-1. On the other hand, cGAMP synthase (cGAS) is another key sensor of HIV-1 $(13,14)$. Activation of cGAS by double-stranded DNA or DNARNA heteroduplex leads to the synthesis of 2' $3^{\prime}$-cGAMP, a mammalian cyclic dinucleotide second messenger with noncanonical $2^{\prime}-5^{\prime}$ phosphodiester linkage, which binds and activates STING to induce IFN production (15-17). Thus, the function of cGAS and STING is highly relevant to HTLV-1 infection.

To circumvent the antiviral action of type I IFNs, viruses have developed various strategies to antagonize IFN production and signaling $(18,19)$. Particularly, HTLV-1 evades IFN production and signaling at multiple steps through multiple mechanisms (20, 21). HTLV-1 suppresses IFN signaling by inducing the expression of SOCS1, an inhibitor of JAK-STAT signaling (22). This induction is mediated by HTLV-1 Tax through NF- $\mathrm{\kappa B}$ (23). Tax is not only the viral transactivator but also an oncoprotein that plays important roles in the initiation of ATL development (24-26). Tax activates viral and cellular transcription primarily through CREB and NF- $\kappa$ B pathways (27-34). In addition, Tax is known to interact with RIG-I, MDA5, TRIF, and RIP1, leading to the inhibition of IRF7 (35). Whereas these findings support the notion that Tax perturbs IFN production and signaling, both TBK1 and IRF3 have also been shown to be activated by Tax, leading to constitutive activation of IFN production $(36,37)$. Thus, further investigations are required to clarify whether HTLV-1 and Tax might induce or suppress type I IFN production.

In this study, we investigated the influence of HTLV-1 on the activation of type I IFN production in both HTLV-1-transformed ATL cells and freshly infected T lymphocytes. We then determined the role and action point of Tax in the modulation of IFN production. Tax mutants defective for the activation of either CREB or NF- $\kappa \mathrm{B}$ were further tested for the ability to affect IFN induction. Finally, the association of Tax with IRF3 kinase TBK1 and the impact of recombinant Tax protein on the kinase activity of TBK1 were determined. Our work defined the negative regulatory role of Tax on IRF3 phosphorylation by TBK1.

\section{MATERIALS AND METHODS}

Cell culture, transfection and infection. HEK293 cells, as well as HTLV-1 ${ }^{-}$(Jurkat and CEMT4) and HTLV-1 ${ }^{+}$(MT2, MT4, and C8166) T cells, were cultured and transfected as previously described $(38,39)$. Infection of cells with Sendai virus (Cantell strain) or vesicular stomatitis virus expressing green fluorescent protein (VSV-GFP) was performed as described previously $(12,40)$. GFP fluorescence was quantified by flow cytometry.

Infection of Jurkat cells with HTLV-1 was achieved through coculture with MT2 cells as described previously (41). Briefly, Jurkat cells were transfected with reporter constructs. After $24 \mathrm{~h}, 2 \times 10^{5}$ or $4 \times 10^{5}$ of MT2 cells were cocultured with the transfected Jurkat cells. Cells were harvested for a dual-luciferase assay after another $24 \mathrm{~h}$.

Plasmids. Luciferase reporter plasmids pLTR-Luc, ркB-Luc, pIRF3Luc, pIFN- $\beta$-Luc, and pISRE-Luc as well as expression vectors for Tax, Tax mutants, RIG-IN, RIG-I, TBK1, IKKe, IRF3, IRF3-5D, and IRF7 have been described in our previous publications (41-44). The expression of target proteins was driven by a strong promoter derived from human cytomegalovirus. Luciferase reporter plasmid pIFN- $\alpha$-Luc containing nucleotides -140 to +9 of human IFN- $\alpha 1$ promoter (45) was kindly provided by Yuan Yan (University of Pennsylvania, Philadelphia, PA). cGAS and STING were subcloned from IMAGE cDNA clones (6015929 and 5762441) and expressed in pCAGEN and pcDNA6B vectors, respectively.

Antibodies and protein analysis. Mouse anti-Tax antibody has been described $(29,46)$. Rabbit anti-TBK1 and anti-phospho-TBK1 (S172) antibodies were purchased from Cell Signaling (Danvers, MA). Mouse anti-V5 antibody was bought from Life Technologies (Grand Island, NY). Mouse anti-HA (Y11), anti-Myc (9E10), and anti-glutathione S-transferase (anti-GST; B14) antibodies were from Santa Cruz Biotechnology (Dallas, TX). Mouse anti-Flag (M2) and rabbit anti-V5 antibodies were from Sigma-Aldrich (St. Louis, MO). Mouse anti- $\beta$-tubulin and rabbit anti-GFP antibodies were from Abcam (Cambridge, MA). Western blotting, native gel electrophoresis analysis of IRF3 dimerization, and coimmunoprecipitation were performed as described previously $(12,40,41)$.

Luciferase reporter assay. Cells were harvested 30 to $48 \mathrm{~h}$ after transfection for dual-luciferase assay as described previously $(12,40)$. Normalization of transfection efficiency was achieved by cotransfection of pSVRLuc reporter (Promega, Madison, WI). Results represented three independent experiments and standard deviations (SD) were indicated. Two-tailed Student $t$ test was carried out to assess the statistical significance of the differences between groups.

RT-PCR. Sendai virus defective interfering (DI) RNA was analyzed by semiquantitative reverse transcription-PCR (RT-PCR). The trailer sequence 5'-ACCAGACAAGAGTTTAAGAGATAT-3' was used as both forward and reverse primers. Procedures for real-time RT-PCR have been detailed elsewhere $(39,40)$. The primer sequences for Tax, IFN- $\beta$, and $\beta$-actin transcripts have also been described $(12,40)$. The normalized value in each sample was calculated from the amount of target RNA relative to $\beta$-actin mRNA. A comparative threshold cycle $\left(C_{T}\right)$ method was used to calculate the relative RNA expression level from $2^{-\Delta \Delta C T}$.

In vitro kinase assay. Recombinant maltose-binding protein (MBP), MBP-tagged Tax (MBP-Tax), and GST-tagged IRF3 protein were purified from Escherichia coli and used for in vitro kinase assay as described previously $(47,48)$. Flag-tagged TBK1 protein was immunoprecipitated from transfected HEK293 cells using anti-Flag antibody (Sigma-Aldrich). In the presence of $\left[\gamma^{-}{ }^{32} \mathrm{P}\right] \mathrm{ATP}$, purified IRF3 and TBK1 proteins were incubated with MBP-Tax. Phosphorylated IRF3 was separated by SDS-PAGE and visualized by autoradiography. The intensity of phosphorylated IRF3 was quantified by densitometry using ImageJ software (v1.48).

\section{RESULTS}

HTLV-1 suppresses the activation of IFN- $\beta$ production. To clarify whether HTLV-1 might activate or inhibit type I IFN production, we compared IFN- $\beta$ induction in three representative HTLV-1-transformed ATL cell lines MT2, MT4, and C8166 versus the two HTLV-1 ${ }^{-}$T lymphocytic cell lines Jurkat and CEMT4. Sendai virus, a common and potent inducer of IFNs, was used to stimulate IFN- $\beta$ production in these cells. Robust expression of Tax transcript was observed in the infected cells (Fig. 1A). Whereas Sendai virus strongly induced IFN- $\beta$ mRNA expression in Jurkat and CEMT4 cells (Fig. 1B, column 2 compared to column 1 and column 4 compared to column 3), no induction was detected in Tax-expressing MT2, MT4, and C8166 cells (Fig. 1B, columns 5 to 10). Sendai virus (Cantell strain) was specifically selected for hyperinduction of type I IFNs, primarily due to overproduction of a copy-back-type defective interfering RNA (DI RNA), which activates PACT and RIG-I $(49,50)$. We verified that this IFN-inducing viral RNA was abundantly expressed in infected T cells (Fig. 1C). However, DI RNA-induced activation of IFN- $\beta$ production was impeded in HTLV-1-transformed cells (Fig. 1B). A similar inhibition of IFN- $\beta$ production was also observed in MT4 and C8166 cells infected with VSV-GFP (Fig. 1D, columns 4 and 6 compared to column 2). Consistent with this inhibition, viral replication, as indicated by the GFP fluorescence, was more 
A

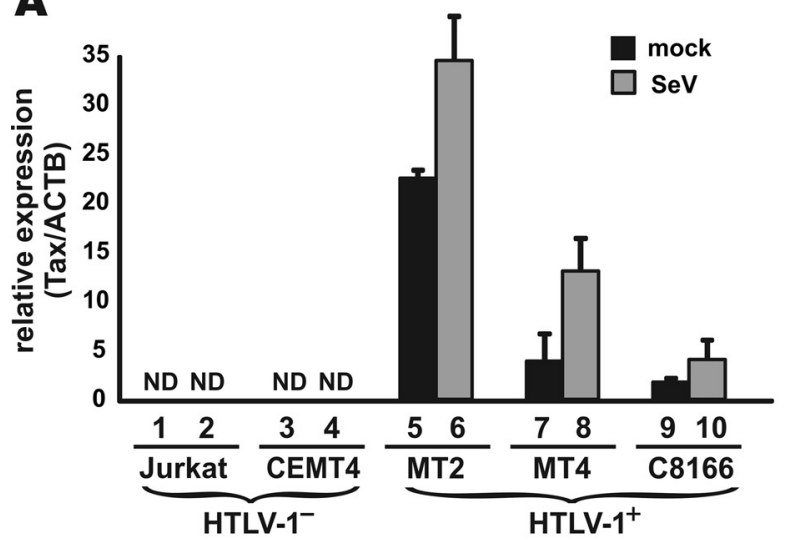

B

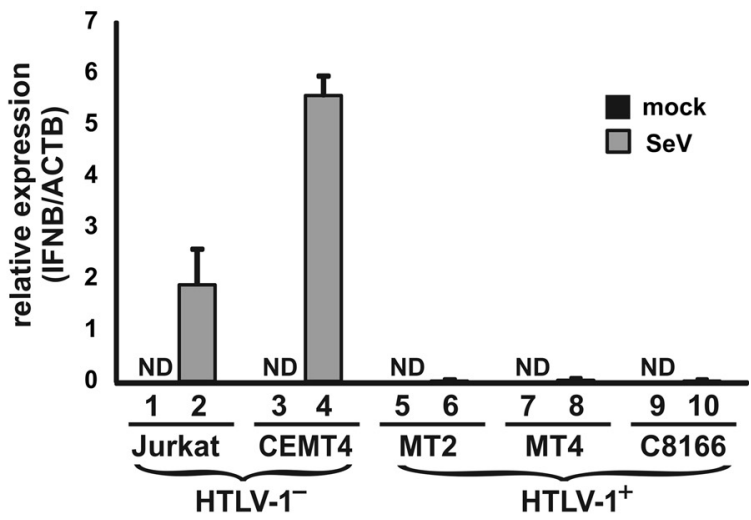

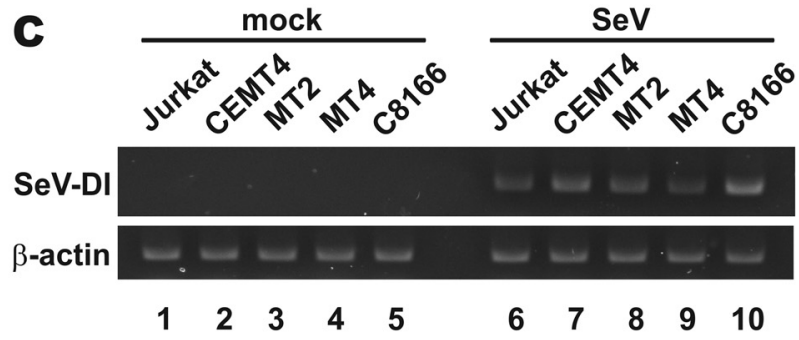

$\mathbf{D}$

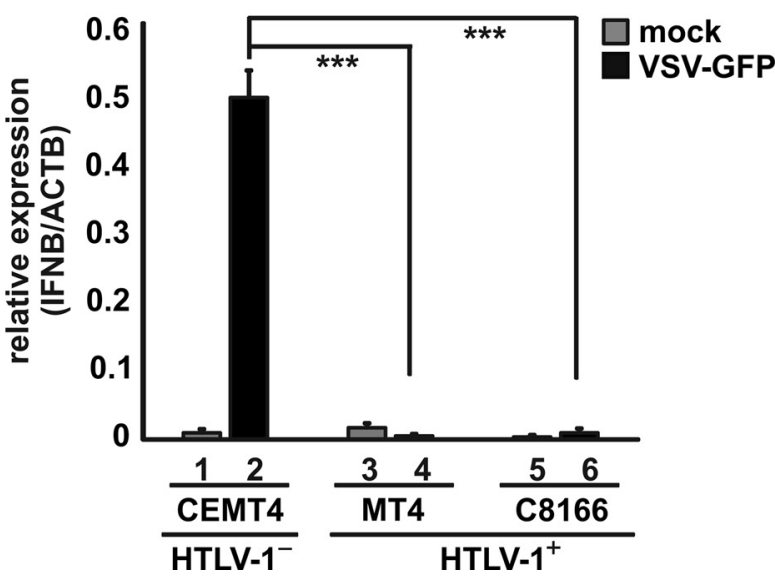

E

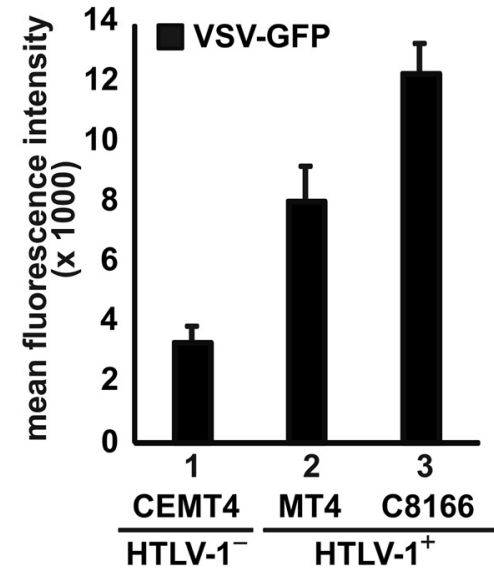

FIG 1 Loss of IFN- $\beta$ induction in HTLV-1-transformed ATL cells. (A and B) Expression of viral and IFN- $\beta$ transcripts. HTLV-1 ${ }^{-}$Jurkat and CEMT4 cells, as well as HTLV $-1^{+}$MT2, MT4, and C8166, were mock infected or infected with Sendai virus (SeV). RNAs were extracted at $24 \mathrm{~h}$ postinfection. The expression of Tax and IFN- $\beta$ (IFNB) transcripts was analyzed by quantitative RT-PCR and normalized to endogenous expression of $\beta$-actin (ACTB) mRNA. Results represent the means \pm the SD of three independent experiments. ND, not detected. (C) RT-PCR analysis of Sendai virus DI RNA (SeV-DI). The band represents a PCR product of 546 bp. (D and E) No induction of IFN- $\beta$ mRNA by VSV-GFP in HTLV-1-transformed cells. Cells were infected with VSV-GFP at a multiplicity of infection of 0.1. Cells were harvested for quantitative RT-PCR and flow cytometric analysis at $24 \mathrm{~h}$ postinfection. The GFP intensity of VSV-GFP-infected cells was determined by flow cytometry. Cells were fixed with freshly prepared $4 \%$ paraformaldehyde. The GFP signal of individual cells was analyzed by BD Biosciences LSRFortessa cell analyzer. Mock-infected cells were used to set the gates for GFP-negative cells. The mean fluorescence intensity of infected cells with GFP signal was calculated using FlowJo software package. ${ }^{* *}, P<0.001$ (Student $t$ test).

robust in MT4 and C8166 cells (Fig. 1E, columns 2 and 3 compared to column 1). Thus, viral induction of IFN- $\beta$ was abrogated in HTLV-1-transformed cells.

Although the loss of IFN- $\beta$ induction in HTLV-1-transformed cells suggested an inhibitory effect of HTLV-1 on type I IFN production, verification in cells freshly infected with HTLV-1 was desirable. Because HTLV-1 is transmitted primarily through virological synapse (51), we infected Jurkat cells through coculture with MT2 cells. IFN- $\beta$ induction by Sendai virus was robust in
Jurkat cells (Fig. 1). To facilitate the detection of IFN- $\beta$ induction, we transfected into Jurkat cells a reporter plasmid driven by multiple copies of IRF3 binding sites, together with an expression vector for a constitutively active mutant of RIG-I named RIG-IN, which contains the N-terminal CARD domains only. Both constructs have been described and used previously (12). Potent activation of the IRF3-Luc reporter by RIG-IN in Jurkat cells was verified (Fig. 2A, columns 2 and 3 compared to column 1). Infection of Jurkat cells by coculture with MT2 was also successful, as 

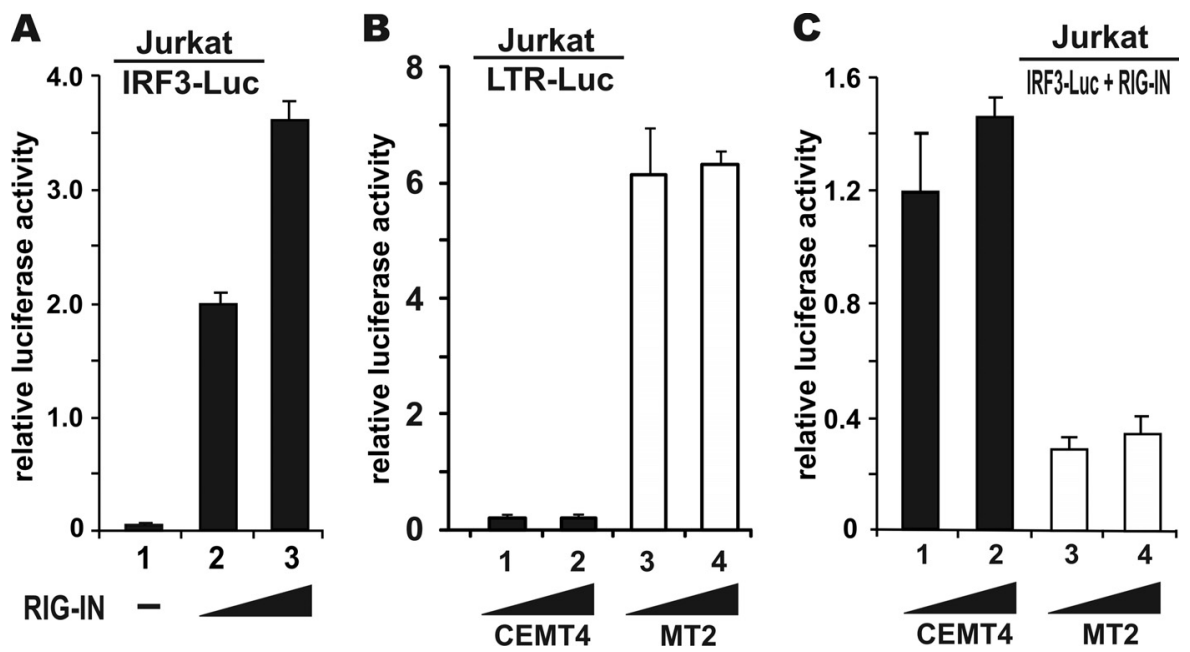

FIG 2 Suppression of IFN- $\beta$ induction in Jurkat cells freshly infected with HTLV-1. (A) Activation of IRF3 reporter by RIG-IN in Jurkat cells. Cells were cotransfected with pIRF3-Luc and escalating amounts of RIG-IN plasmid. Cells were harvested for dual-luciferase assays after $48 \mathrm{~h}$. Only 5 to $10 \%$ of Jurkat cells were transfected, as verified by confocal microscopy. (B) Verification of LTR activation. Jurkat cells were transfected with pLTR-Luc. After 24 h, escalating numbers $\left(2 \times 10^{5}\right.$ and $\left.4 \times 10^{5}\right)$ of CEMT4 or MT2 cells were cocultured with the transfected Jurkat cells. Cells were harvested and assayed for dual-luciferase activity after another $24 \mathrm{~h}$. (C) Analysis of IRF3 reporter activity. Jurkat cells were transfected with pIRF3-Luc reporter and RIG-IN expression plasmid. Coculture and a dual-luciferase assay were carried out essentially as described for panel B.

indicated by the robust LTR-Luc activity recovered from Jurkat cells (Fig. 2B, columns 3 and 4 compared to columns 1 and 2). Notably, the IRF3-Luc activity was dampened in Jurkat cells cocultured with MT2 cells compared to Jurkat cells cocultured with CEMT4 cells (Fig. 2C, columns 3 and 4 compared columns to 1 and 2). Hence, IRF3 activation was compromised in Jurkat cells freshly infected with HTLV-1.

Suppression of IRF3 activation by HTLV-1 Tax. As discussed above, we noticed an inverse correlation of Tax expression with IFN- $\beta$ induction or IRF3 activation in HTLV-1-infected cells (Fig. 1 and 2). To determine whether Tax could sufficiently suppress IRF3 activation, we performed additional luciferase assay in Jurkat cells. Although the transfection efficiency in Jurkat cells was low, a trend for the dose-dependent suppression of RIG-IN-induced activation of IRF3 transcriptional activity by Tax was evident (Fig. $3 \mathrm{~A}$, columns 6 to 8 compared to column 5). Complementary to this, we observed that RIG-IN-induced IRF3 dimerization was less pronounced in HEK293 cells when Tax was expressed (Fig. 3B, lanes 3 and 4 compared to lane 2 ). These results consistently supported the suppression of IRF3 activation by Tax.

Tax suppresses IFN- $\beta$ induction at the step of IRF3 phosphorylation. We next sought to pinpoint the key step perturbed by Tax in its suppression of IFN- $\beta$ induction by epistatic analysis. The induction of type I IFN production is governed by signal transduction pathways in which an activation signal is relayed by a cascade of signaling proteins to IRF3 and IRF7 transcription factors which switch on IFN promoters (7). Particularly, RNA recognition by RIG-I emanates an activation signal that is passed on sequentially to MAVS, TBK1, IKKe, IRF3, and IRF7 (8, 52-55). Theoretically, Tax should suppress the effect of all upstream inducers, but it had no influence on the effect of its downstream effectors. Therefore, the action point of Tax can be determined by assessing its suppressive effects on a series of transducer proteins. As the first step, we chose to evaluate the impact of Tax on the
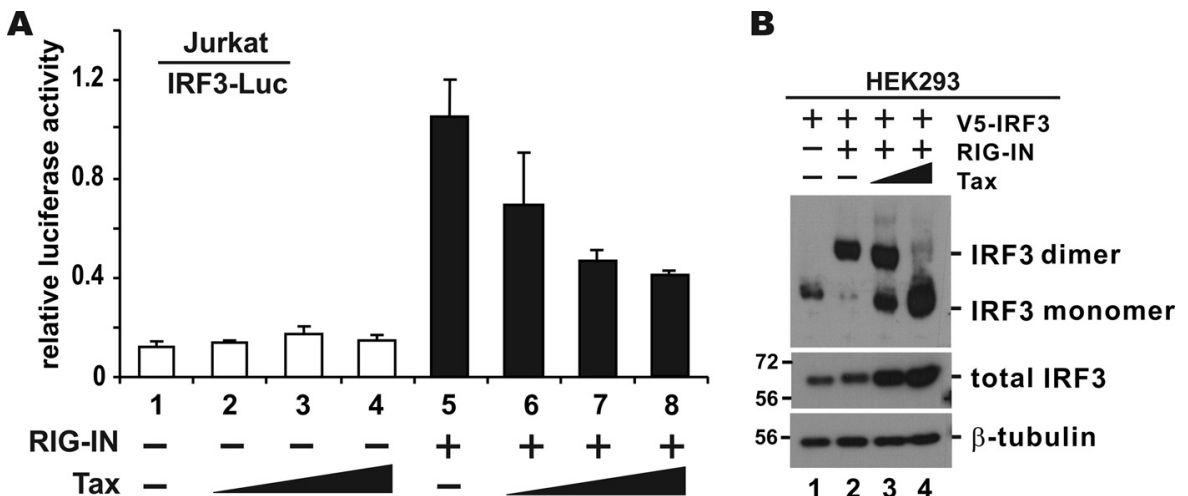

FIG 3 Suppression of IRF3 activation by Tax. (A) Reporter assay. Jurkat cells were cotransfected with pIRF3-Luc, RIG-IN plasmid and escalating doses of Tax expression construct. (B) Native gel analysis of IRF3 dimerization. HEK293 cells were transfected with expression plasmids for V5-tagged IRF3 (V5-IRF3), RIG-IN, and Tax. After $24 \mathrm{~h}$, the cells were lysed, and the dimerization of IRF3 was analyzed using native gel electrophoresis. Total IRF3 and $\beta$-tubulin were resolved by SDS-PAGE as internal controls. 
A

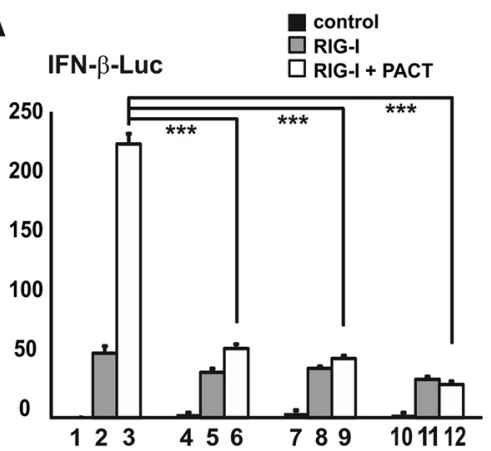

Tax -

D
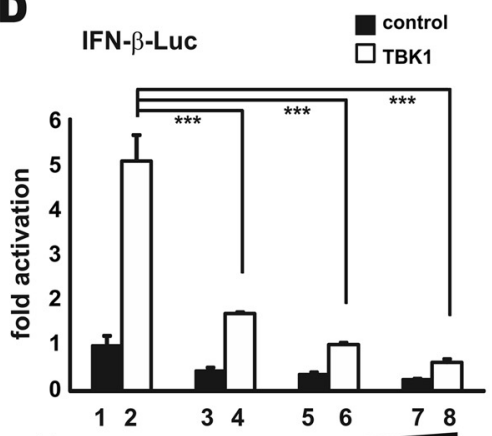

Tax -
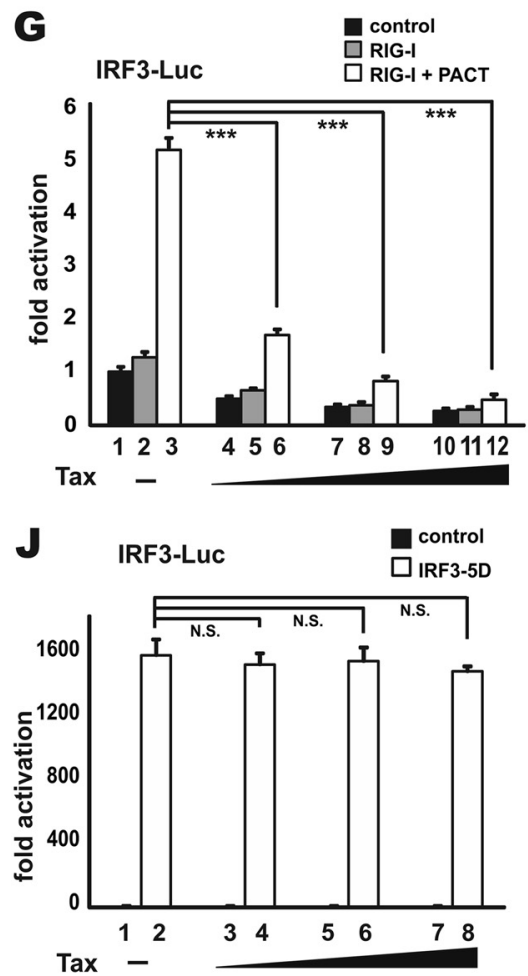

B

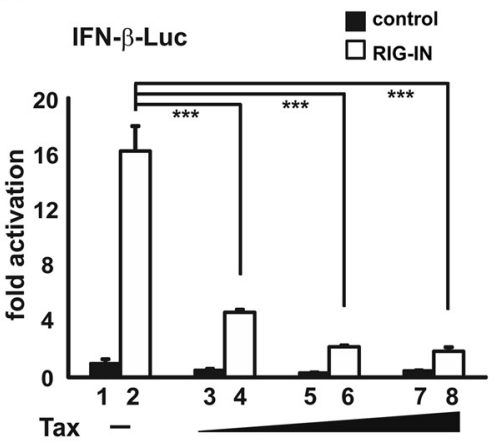

E
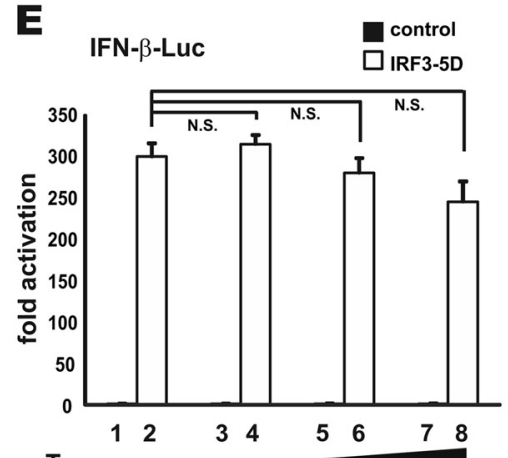

Tax -

H

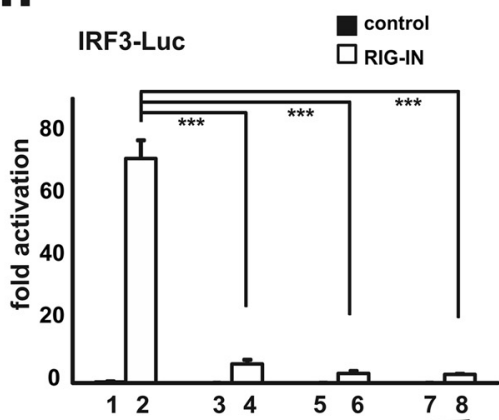

Tax -

$\mathbf{K}$

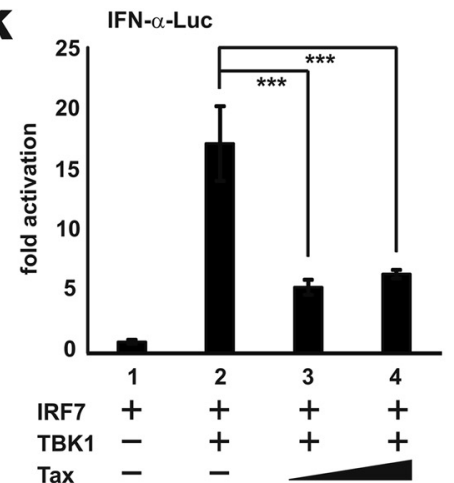

C
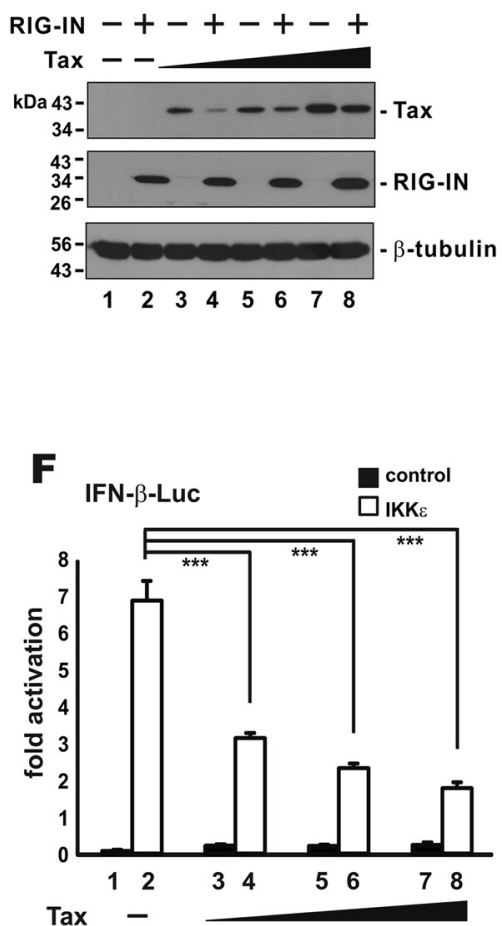

I

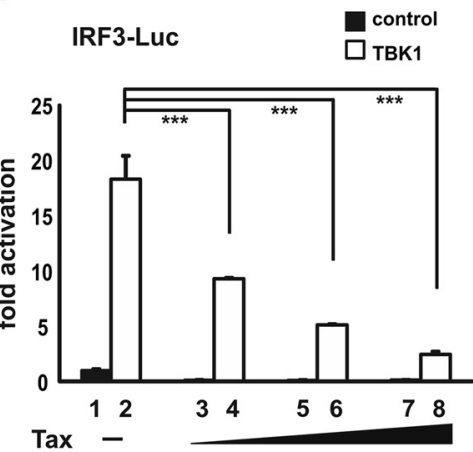

L

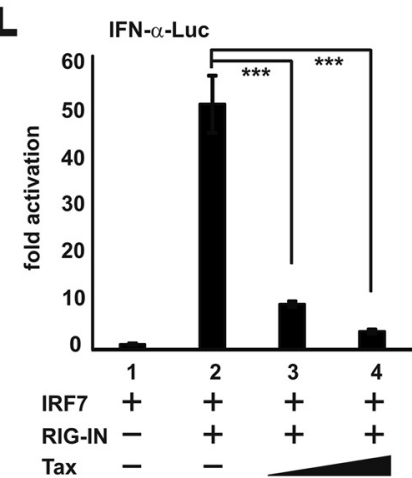

FIG 4 Inhibition of IRF3 activation by Tax. (A to L) HEK293 cells were transfected with the indicated reporters, together with a fixed amount (100 ng) of expression plasmids for activator proteins and increasing doses of Tax plasmid (1,10, and $100 \mathrm{ng})$. At $30 \mathrm{~h}$ posttransfection, the cells were harvested for dual-luciferase assays. The results were statistically analyzed by Student $t$ test. (C) Representative Western blot indicating target protein expression. ${ }^{* * *} P<$ 0.001 ; N.S., not significant. 

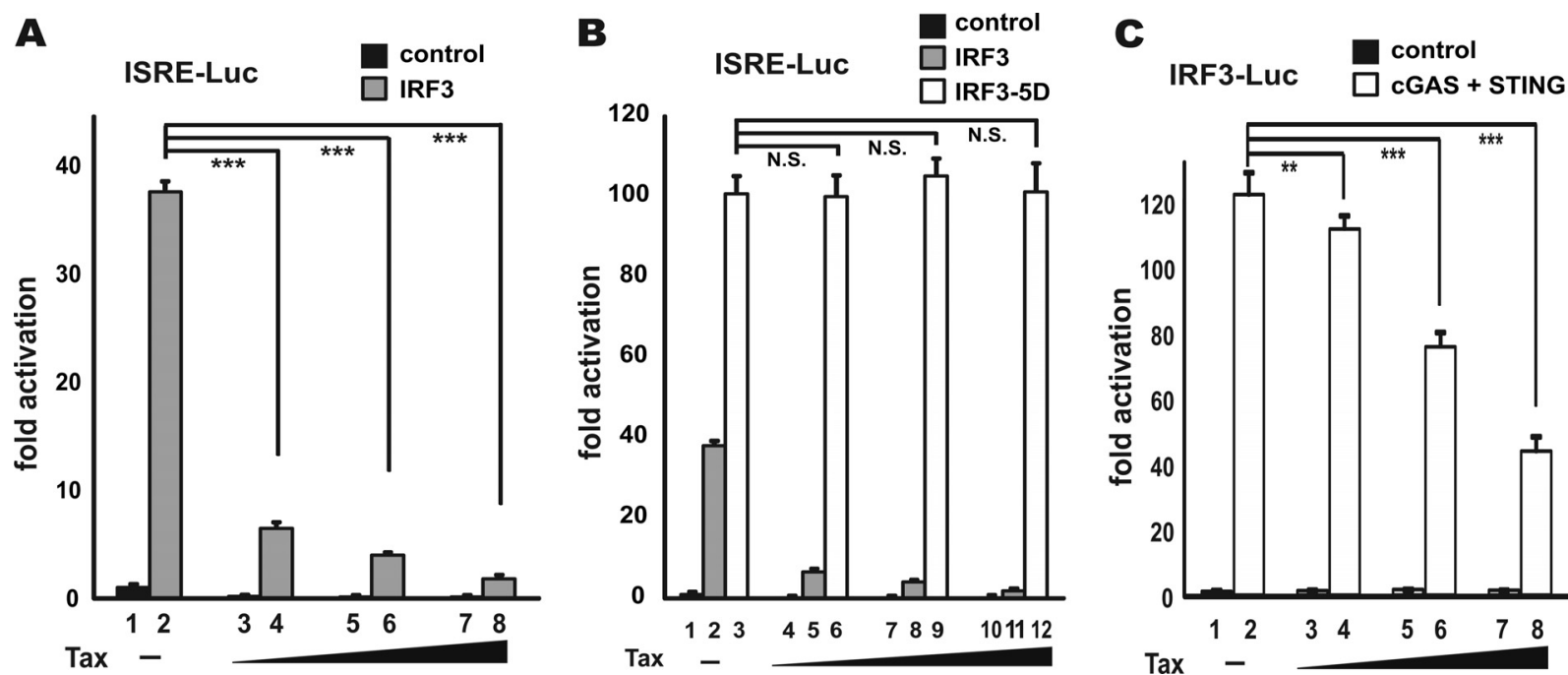

FIG 5 (A to C) Inhibition of IRF3 and cGAS activity by Tax. HEK293 cells were transfected, and a luciferase assay was performed as in Fig. $4 .{ }^{* * *}, P<0.001$; ${ }^{* *}$, $P<0.01$; N.S., not significant.

IFN-inducing activity of RIG-I, RIG-I+PACT, RIG-IN, TBK1, IKKE, IRF3-5D, and IRF7. IRF3-5D is a phosphomimetic and constitutively active mutant in which five TBK1 phosphorylation sites are replaced by Asp (56). Three reporter plasmids PIFN- $\alpha$ Luc, pIFN- $\beta$-Luc, and PIRF3-Luc were used in our experiments. Whereas IFN- $\alpha$-Luc and IFN- $\beta$-Luc activities, respectively, reflect the levels of IFN- $\alpha 1$ and IFN- $\beta$ production, the IRF3-Luc activity more specifically indicates the amount of activated IRF3 (12). The expression of target proteins in the transfected cells was verified by Western blotting (see Fig. 4C for one example). Interestingly, Tax was found to potently inhibit both IFN- $\beta$-Luc and IRF3-Luc activity induced by RIG-I+PACT, RIG-IN, TBK1, and IKKe (Fig. $4 \mathrm{~A}, \mathrm{~B}$, and D to I). Tax also repressed the activation of IFN- $\alpha$-Luc activity by IRF7 (Fig. 4K and L). In contrast, Tax had no influence on the activity of IRF3-5D (Fig. 4E and J). We therefore reasoned that Tax might act at the step of IRF3 phosphorylation.

To strengthen our existing data, a fourth reporter construct pISRE-Luc was used to compare the effect of Tax on IRF3 and IRF3-5D. Reporter expression in the pISRE-Luc plasmid is driven by IFN-stimulated response element (ISRE) found in ISGs. It is therefore a more sensitive indicator of IFN production and signaling (12). Interestingly, whereas the activity of IRF3 to activate ISRE was fully susceptible to Tax inhibition (Fig. 5A, columns 4, 6, and 8 compared to column 2), the activity of IRF-5D was unaffected by Tax (Fig. 5B, columns 6, 9, and 12 compared to column 3). These results lent further support to the notion that Tax acts at the step of IRF3 phosphorylation.

Above, we tested the suppressive effect of Tax on the RIG-I pathway. However, recent evidence suggests that the cGAS pathway is more relevant to retroviral infection $(13,14)$. Thus, we set out to assess the impact of Tax on cGAS activation. To reconstitute cGAS signaling in HEK293 cells, the coexpression of cGAS and STING is required (15). In HEK293 cells expressing both cGAS and STING, Tax exhibited a moderate and dosedependent suppressive effect on cGAS-induced activation of IRF3-Luc activity (Fig. 5C, columns 4, 6, and 8 compared to column 2). Thus, Tax was capable of suppressing both RIG-I and cGAS signaling.
Tax suppression of IFN- $\beta$ production is independent of CREB or NF- $\kappa B$ activation. Tax is a well-characterized activator of both CREB and NF-кB signaling (27-34). To determine the requirement of CREB and NF- $\kappa B$ activation for Tax suppression of IFN- $\beta$ induction, we took advantage of the previously characterized Tax mutants that are defective for activation of either CREB or NF- $\mathrm{BB}(28,57,58)$. Particularly, Tax L320G mutant can activate NF- $\kappa B$ but not CREB $(28,58)$, whereas Tax H43Q and S258A mutants $(28,58)$, as well as a T130A L131S mutant named M22 (57), are defective for NF- $\kappa$ B activation but retain the ability to activate CREB. To our surprise, all Tax mutants exhibited an inhibitory effect on RIG-IN-induced IFN- $\beta$ production comparable to wild-type Tax (Fig. 6A, columns 6, 8, 10, and 12 compared to column 4). Additionally, the M22 mutant also retained the ability to confer dose-dependent suppression of cGAS activation (Fig. 6B, columns 4, 6, and 8 compared to column 2), which is similar to that of wild-type Tax on IRF3 activation (Fig. 5C). The activity profiles of Tax and its mutants on the activity of LTR-Luc and $\kappa \mathrm{B}$-Luc were validated (Fig. 6C and D). The LTR-Luc activity reflects the ability of Tax to activate CREB (28). Because Tax and its mutants were capable of activating LTR-Luc or кB-Luc to similar magnitude (Fig. 6C and D), they were expressed to comparable levels in transfected cells. Collectively, our results suggested that the ability to activate CREB or NF- $\mathrm{\kappa B}$ is dispensable for Tax suppression of type I IFN induction.

Tax associates with TBK1 and inhibits TBK1 phosphorylation of IRF3. Since Tax was capable of suppressing the activity of TBK1 but not IRF3-5D (Fig. 4 and 5), we reasoned that Tax might exert an inhibitory role directly on TBK1, the key protein kinase for phosphorylation of IRF3, which is in turn the key transcription factor activating IFN promoters $(52,53,59-61)$. To test this model, we first performed reciprocal immunoprecipitation and immunoblotting assays to examine the association of Tax with TBK1. When we precipitated Tax from MT2, MT4, and C8166 cells, TBK1 was detected in the Tax-containing immune complex (Fig. 7A, lanes 3 to 5 compared to lanes 1 and 2). Consistently, Tax was also found in the TBK1 immunoprecipitate from MT4 and C8166 cells (Fig. 7B). These results demon- 
A IFN- $\beta$-Luc
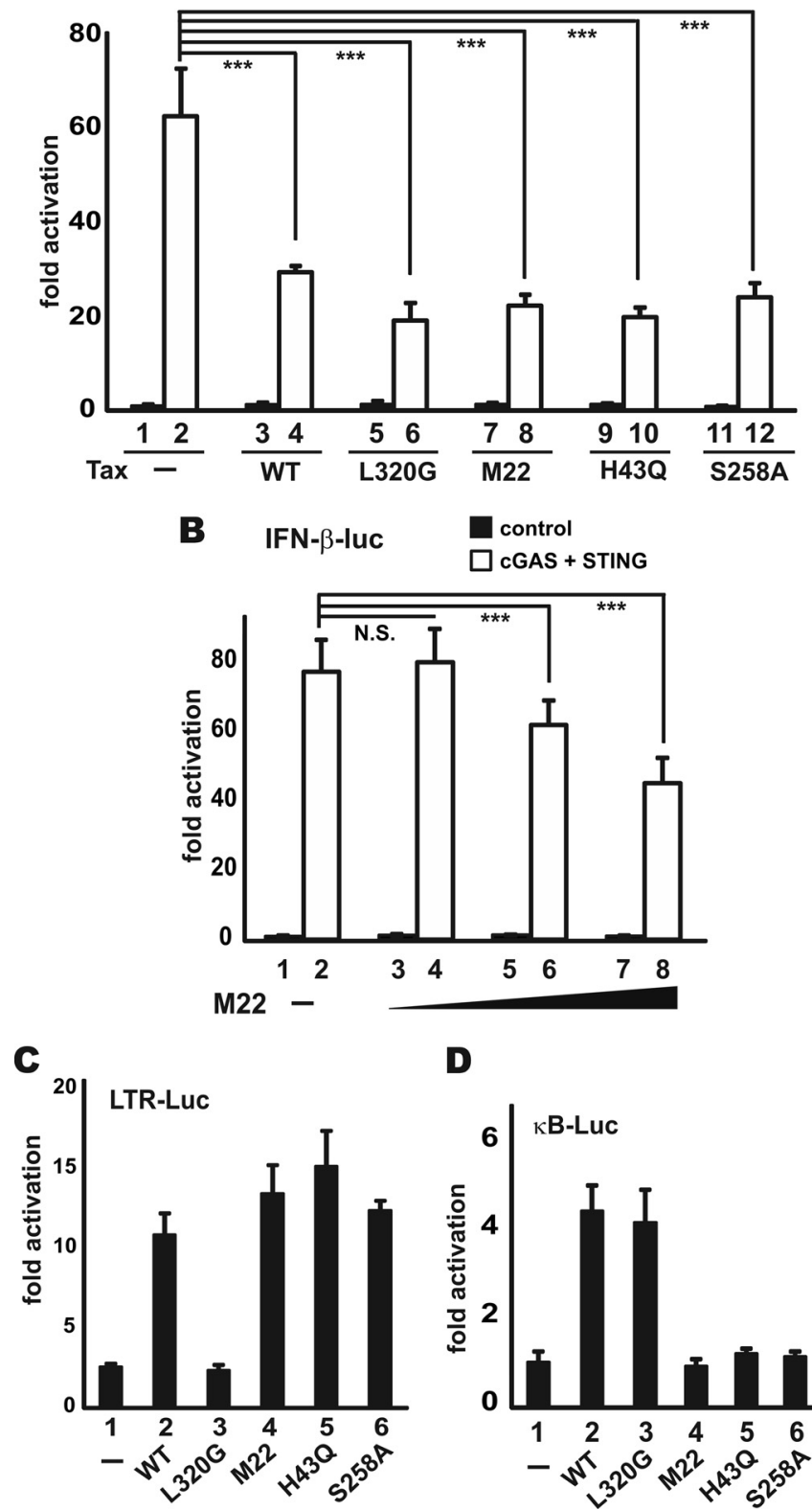

D

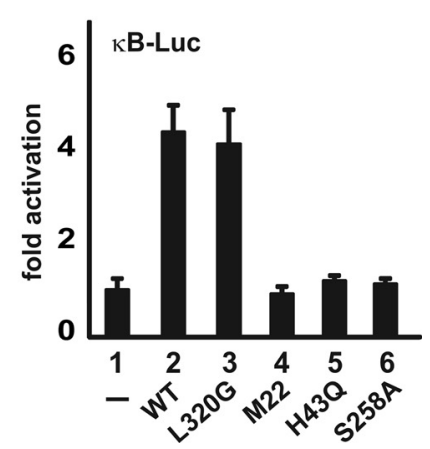

FIG 6 Tax inhibition of IFN- $\beta$ production does not require CREB or NF- $\kappa$ B activation. (A) Activity of RIG-IN; (B) activity of cGAS; (C and D) verification of the activity of Tax mutants on LTR and $\kappa B$ promoters. HEK293 cells were transfected, and luciferase assays were performed as in Fig. 4.

strated the association of Tax with endogenous TBK1 in HTLV-1-transformed cells.

Because IKKE, STING, and IRF3 have also been found in the TBK1 complex $(52-55,60)$, we performed additional coimmunoprecipitation assays in transfected HEK293 cells to determine whether Tax might also associate with these proteins. Not to our surprise, Tax was detected in the IKKE and IRF3 precipitates (Fig. 7C and E, lane 3), whereas STING was also found in the immunoprecipitate that contains Tax (Fig, 7D, lane 3).
Hence, Tax likely forms a complex with TBK1 and other TBK1interacting proteins.

We next investigated how the binding of Tax with TBK1 might affect IRF3 kinase activity of the latter. An in vitro kinase assay was performed with recombinant MBP-Tax and GSTIRF3 proteins purified from E. coli (Fig. 8A), as well as TBK1 precipitated from transfected HEK293 cells (Fig. 8B). Incubation of GST-IRF3 with TBK1 resulted in the phosphorylation of GST-IRF3 (Fig. 8C, lane 2 compared to lane 1). The addition of progressively increasing amounts of MBP-Tax into the phosphorylation reaction led to dose-dependent reduction of the levels of phosphorylated GST-IRF3 (Fig. 8C and D, lanes 3 to 7 compared to lane 8). In our experimental setting TBK1 autophosphorylation was not observed (Fig. 8C, lane 9 compared to lane 10). In another experiment, Tax expression in HEK293 cells had no influence on the induction of TBK1 phosphorylation by RIG-IN (Fig. 8E, lanes 3 to 5 compared to lane 2). Taken together, Tax exerted an inhibitory effect on the IRF3 kinase activity of TBK1.

\section{DISCUSSION}

We demonstrated in this study the suppression of TBK1-mediated phosphorylation of IRF3 by HTLV-1 Tax. Type I IFN induction was impaired in HTLV-1-transformed ATL cells and in T lymphocytic cell line freshly infected with HTLV-1. The suppression of IFN production was sufficiently executed by Tax oncoprotein. This suppressive role of Tax on IFN induction did not require the ability to activate either CREB or NF$\kappa \mathrm{B}$. The action point at which Tax antagonizes IFN induction was determined. The association of Tax with TBK1 and the consequent inhibition of the IRF3 kinase activity of TBK1 lent further support to the notion that Tax perturbs IRF3 phosphorylation.

Generally consistent with previous findings on Tax induction of SOCS1 $(22,23)$ and Tax interaction with RIP1, leading to the inhibition of IRF7 (35), our work provides a new mechanism by which HTLV-1 evades an innate IFN response (Fig. 8F). In other words, at least three routes operate in the suppression of innate IFN production and signaling by Tax. Because type I IFNs and ISGs are capable of inhibiting HTLV-1 replication, viral evasion of IFN production and signaling is logical and probably represents a survival strategy. This is important in all stages of viral infection, including both the initial and the persistent phases. Although some technical details reported in the different papers might differ, these studies are generally complementary to our work. Tax is known to be multifunctional, and it is not surprising that it acts through multiple mechanisms that are not mutually exclusive. For example, the association of Tax with RIG-I, TRIF, and RIP1 reported in the another study (35) might also contribute to the inhibitory effect on TBK1 and IRF3 observed in our work. On the other hand, the inhibition of TBK1 by Tax demonstrated here could result in the previously reported inhibition of IRF7 (35), which was also observed in our study. Notably, our findings also provide the first evidence for Tax suppression of the cGAS-STING pathway, which also plays an important role in the sensing of HTLV-1 infection (62). In this regard, it will be of interest to elucidate how cGAS cooperates with STING to sense HTLV-1 and whether Tax might perturb the sensing or consequent intracellular signaling events more directly.

Our work directly contradicts two previous reports that 
A
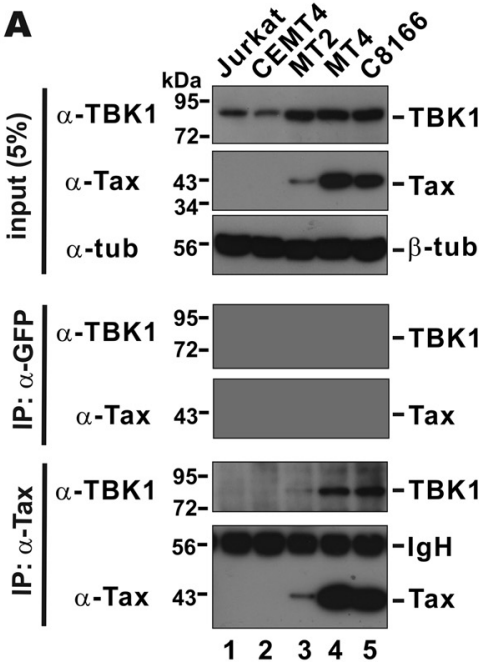

C

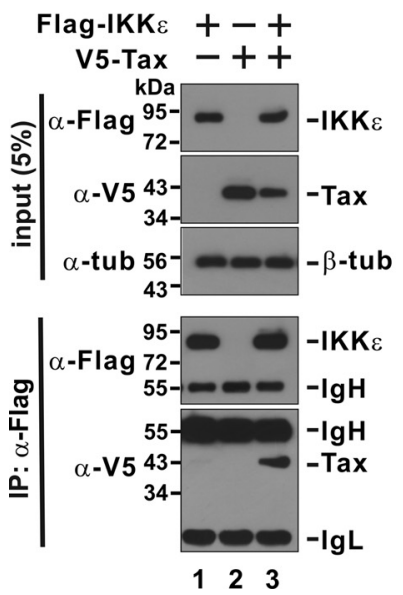

D

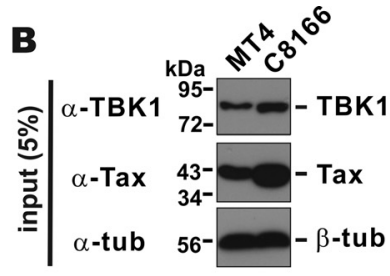

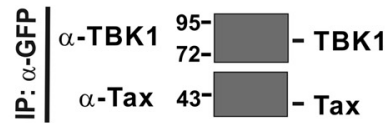

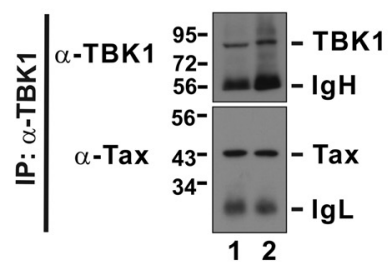

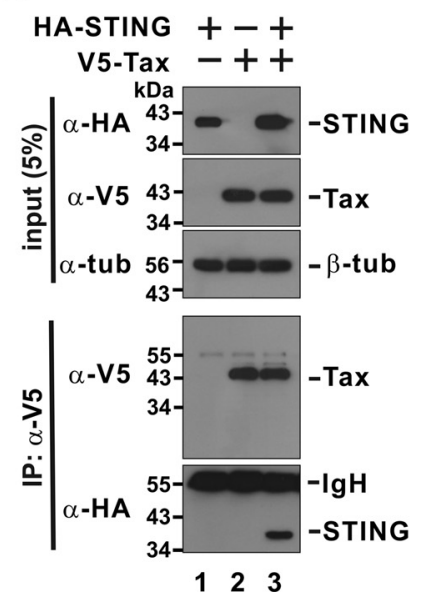

E

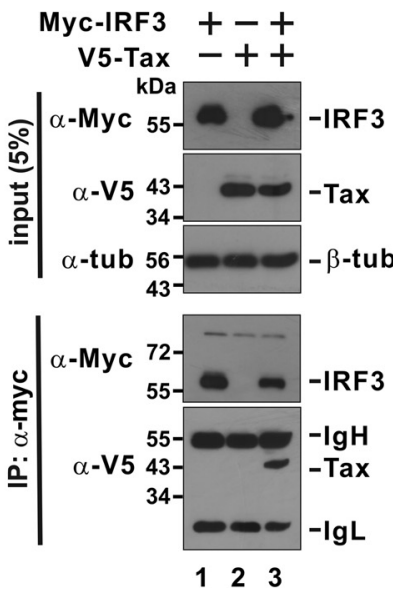

FIG 7 (A to E) Association of Tax with TBK1, IKKE, STING, and IRF3. Coimmunoprecipitation was performed reciprocally using the indicated antibodies. Tax was not detected in the TBK1 complex immunoprecipitated from Jurkat or CEMT4 cells (data not shown). In panels C to E, HEK293 cells were transfected with plasmids expressing the indicated proteins. IP, immunoprecipitation; $\beta$-tub, $\beta$-tubulin; IgH, immunoglobulin heavy chain; IgL, immunoglobulin light chain.

claimed the activation of TBK1, IRF3, and IFN production by Tax $(36,37)$. Our findings that IFN- $\beta$ induction was compromised in HTLV-1-infected cells did not support the claim for activation of IFN induction. Although the interaction of Tax with TBK1 was shown in our work and another recent study (37), the functional consequence reported in these two studies was completely opposite. Our finding on Tax inhibition of TBK1 activity was supported by a cluster of evidence obtained from different cells and using different experimental approaches. First, IFN- $\beta$ induction was compromised but not activated in HTLV-1-infected cells. Second, Tax sufficiently inhibited and did not activate IRF3 dimerization or IRF3 activity in Jurkat or HEK293 cells. Finally, Tax inhibited the activity of TBK1 to phosphorylate IRF3 and to induce IFN- $\beta$. We do not understand whether differences in experimental systems, sublines of cells, and other technical details might account for the opposite observations. It remains to be seen whether the previously reported activation of TBK1, IRF3, and type I IFN production by Tax and HTLV-1 $(36,37)$ might be biologically relevant to particular stage of HTLV-1 infection during which viral replication is severely inhibited. Overexpression systems are prone to artifacts and nonphysiological results. To strengthen our results obtained from overexpression in HEK293 cells, we tested IFN induction in both HTLV-1-transformed cells and freshly infected Jurkat cells, verified the suppressive effect of Tax in Jurkat cells, directly assayed for IRF3 dimerization, and performed in vitro IRF3 phosphorylation assay with recombinant Tax and IRF3 proteins. Thus, our results obtained from different systems and assays corroborated with each other to support an inhibitory effect of Tax on IRF3 phosphorylation by TBK1.

We obtained similar findings with TBK1 and the related kinase IKKع. To our surprise, neither CREB nor NF- $\mathrm{B}$ activation was required for the suppressive effect of Tax on type I IFN induction. For its activation of CREB and NF- $\kappa \mathrm{B}$ signaling, Tax interacts with and modulates the activity of various kinases, including their regulatory subunits such as IKK $\gamma(47,63,64)$. Probably, Tax exerts its regulatory function on different kinases through different mechanisms. In this regard, further investigations are required to elu- 

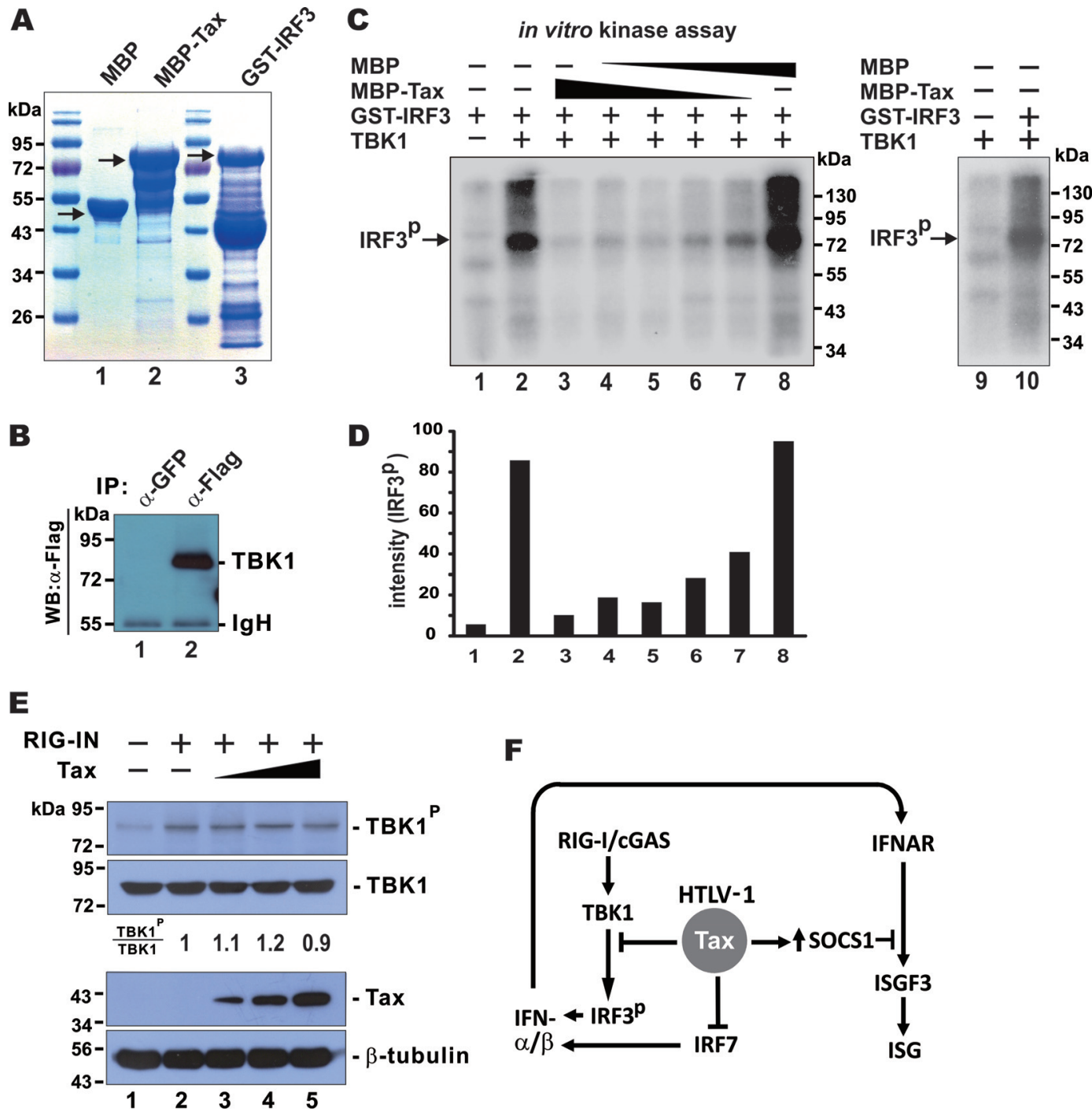

FIG 8 Inhibition of TBK1 kinase activity by Tax. (A) Verification of the purity of recombinant proteins. (B) Verification of TBK1 in the immunoprecipitate. (C) Kinase assay was performed with purified GST-IRF3, TBK1, and MBP-Tax proteins in the presence of $\left[\gamma^{-32} \mathrm{P}\right]$ ATP. Phosphorylated IRF3 (IRF3 ${ }^{\mathrm{P}}$ ) was separated by SDS-PAGE and visualized by autoradiography. (D) Densitometric analysis of phosphorylated IRF3. (E) Influence of Tax on RIG-IN-induced phosphorylation of TBK1 in HEK293 cells. (F) Schematic diagram illustrating Tax suppression of IFN production and signaling.

cidate the mechanism by which Tax inhibits TBK1 and IKKe. A recent study revealed that phosphorylation of MAVS, STING, and TRIF by TBK1 is another essential step for IRF3 activation (53). In light of this new information, it is tempting to suggest that Tax might target the phosphorylation of other substrates by TBK1. This is compatible with the association of Tax with TRIF demonstrated in a previous study (35). Plausibly, this might lead to a unifying model for Tax perturbation of IFN production. Thus, it will be of particularly great interest to elucidate whether Tax might indeed suppress TBK1 phosphorylation of TRIF, MAVS, and STING.

A combination of IFN- $\alpha$ and zidovudine has been recommended as the standard first-line therapy for ATL (1-4). Exactly how this combination achieved optimal therapeutic effect remains to be elucidated. Because HTLV-1 is capable of suppressing IFN production and signaling effectively, the anti-HTLV-1 activity of zidovudine might be required for the execution of the anti- proliferative and immunomodulatory activity of IFN- $\alpha$. A better understanding of the mechanism by which Tax oncoprotein perturbs IFN production and signaling in HTLV-1-infected cells would allow us to identify agents and strategies to counteract Tax and reestablish innate IFN response which might have therapeutic benefits. For example, both RIG-I and STING agonists have shown broad-spectrum antiviral effects $(50,65,66)$. It will be of interest to see whether some of these agents might prove useful in the treatment of ATL.

\section{ACKNOWLEDGMENTS}

We thank members of Jin and Kok laboratories for critical reading of the manuscript.

This study was supported by the S. K. Yee Medical Research Fund (2011), the Hong Kong Research Grant Council (HKU1/CRF/11G, HKU7674/12M, HKU7686/13M, and C7011-15R), and the Hong Kong Health and Medical Research Fund (15140682). 


\section{FUNDING INFORMATION}

S. K. Yee Medical Research Fund provided funding to Dong-Yan Jin under grant number 2011. Hong Kong Research Grant Council provided funding to Dong-Yan Jin under grant numbers HKU1/CRF/11G, HKU7674/12M, HKU7686/13M, and C7011-15R. Hong Kong Health and Medical Research Fund provided funding to Dong-Yan Jin under grant number 15140682 .

\section{REFERENCES}

1. Bazarbachi A, Suarez F, Fields P, Hermine O. 2011. How I treat adult T-cell leukemia/lymphoma. Blood 118:1736-1745. http://dx.doi.org/10 .1182/blood-2011-03-345702.

2. Ishitsuka K, Tamura K. 2014. Human T-cell leukaemia virus type I and adult T-cell leukaemia-lymphoma. Lancet Oncol 15:e517-e526. http://dx .doi.org/10.1016/S1470-2045(14)70202-5.

3. Gill PS, Harrington W, Jr, Kaplan MH, Ribeiro RC, Bennett JM, Liebman HA, Bernstein-Singer M, Espina BM, Cabral L, Allen S, Kornblau S, Pike MC, Levine AM. 1995. Treatment of adult T-cell leukemia-lymphoma with a combination of interferon $\alpha$ and zidovudine. N Engl J Med 332:1744-1748. http://dx.doi.org/10.1056/NEJM 199506293322603

4. Hermine O, Bouscary D, Gessain A, Turlure P, Leblond V, Franck N, Buzyn-Veil A, Rio B, Macintyre E, Dreyfus F, Bazarbachi A. 1995. Treatment of adult T-cell leukemia-lymphoma with zidovudine and interferon $\alpha$. N Engl J Med 332:1749-1751. http://dx.doi.org/10.1056 /NEJM199506293322604.

5. Samuel CE. 2001. Antiviral actions of interferons. Clin Microbiol Rev 14:778-809. http://dx.doi.org/10.1128/CMR.14.4.778-809.2001.

6. González-Navajas JM, Lee J, David M, Raz E. 2012. Immunomodulatory functions of type I interferons. Nat Rev Immunol 12:125-135. http: //dx.doi.org/10.1038/nri3133.

7. Kagan JC, Barton GM. 2014. Emerging principles governing signal transduction by pattern-recognition receptors. Cold Spring Harb Perspect Biol 7:a016253. http://dx.doi.org/10.1101/cshperspect.a016253.

8. Yoneyama M, Onomoto K, Jogi M, Akaboshi T, Fujita T. 2015. Viral RNA detection by RIG-I-like receptors. Curr Opin Immunol 32:48-53. http://dx.doi.org/10.1016/j.coi.2014.12.012.

9. Dempsey A, Bowie AG. 2015. Innate immune recognition of DNA: a recent history. Virology 479-480:146-152. http://dx.doi.org/10.1016/j .virol.2015.03.013.

10. Schneider WM, Chevillotte MD, Rice CM. 2014. Interferon-stimulated genes: a complex web of host defenses. Annu Rev Immunol 32:513-545. http://dx.doi.org/10.1146/annurev-immunol-032713-120231.

11. Berg RK, Melchjorsen J, Rintahaka J, Diget E, Søby S, Horan KA, Gorelick RJ, Matikainen S, Larsen CS, Ostergaard L, Paludan SR, Mogensen TH. 2012. Genomic HIV RNA induces innate immune responses through RIG-I-dependent sensing of secondary-structured RNA. PLoS One 7:e29291. http://dx.doi.org/10.1371/journal.pone.0029291.

12. Kok KH, Lui PY, Ng MHJ, Siu KL, Au SWN, Jin DY. 2011. The double-stranded RNA-binding protein PACT functions as a cellular activator of RIG-I to facilitate innate antiviral response. Cell Host Microbe 9:299-309. http://dx.doi.org/10.1016/j.chom.2011.03.007.

13. Gao D, Wu J, Wu YT, Du F, Aroh C, Yan N, Sun L, Chen ZJ. 2013. Cyclic GMP-AMP synthase is an innate immune sensor of HIV and other retroviruses. Science 341:903-906. http://dx.doi.org/10.1126 /science.1240933.

14. Yoh SM, Schneider M, Seifried J, Soonthornvacharin S, Akleh RE, Olivieri KC, De Jesus PD, Ruan C, de Castro E, Ruiz PA, Germanaud D, des Portes V, García-Sastre A, König R, Chanda SK. 2015. PQBP1 is a proximal sensor of the cGAS-dependent innate response to HIV-1. Cell 161:1293-1305. http://dx.doi.org/10.1016/j.cell.2015.04.050.

15. Sun L, Wu J, Du F, Chen X, Chen ZJ. 2013. Cyclic GMP-AMP synthase is a cytosolic DNA sensor that activates the type I interferon pathway. Science 339:786-791. http://dx.doi.org/10.1126/science.1232458.

16. Cai X, Chiu YH, Chen ZJ. 2014. The cGAS-cGAMP-STING pathway of cytosolic DNA sensing and signaling. Mol Cell 54:289-296. http://dx.doi .org/10.1016/j.molcel.2014.03.040.

17. Mankan AK, Schmidt T, Chauhan D, Goldeck M, Höning K, Gaidt M, Kubarenko AV, Andreeva L, Hopfner KP, Hornung V. 2014. Cytosolic RNA:DNA hybrids activate the cGAS-STING axis. EMBO J 33:2937-2946. http://dx.doi.org/10.15252/embj.201488726.

18. Versteeg GA, García-Sastre A. 2010. Viral tricks to grid-lock the type I interferon system. Curr Opin Microbiol 13:508 -516. http://dx.doi.org/10 $.1016 /$ j.mib.2010.05.009.

19. Randall RE, Goodbourn S. 2008. Interferons and viruses: an interplay between induction, signaling, antiviral responses and virus countermeasures. J Gen Virol 89:1-47. http://dx.doi.org/10.1099/vir.0.83391-0.

20. Journo C, Mahieux R. 2011. HTLV-1 and innate immunity. Viruses 3:1374-1394. http://dx.doi.org/10.3390/v3081374.

21. van Montfoort N, Olagnier D, Hiscott J. 2014. Unmasking immune sensing of retroviruses: interplay between innate sensors and host effectors. Cytokine Growth Factor Rev 25:657-668. http://dx.doi.org/10.1016 /j.cytogfr.2014.08.006.

22. Olière $S$, Hernandez E, Lézin A, Arguello M, Douville R, Nguyen TL, Olindo S, Panelatti G, Kazanji M, Wilkinson P, Sékaly RP, Césaire R, Hiscott J. 2010. HTLV-1 evades type I interferon antiviral signaling by inducing the suppressor of cytokine signaling 1 (SOCS1). PLoS Pathog 6:e1001177. http://dx.doi.org/10.1371/journal.ppat.1001177.

23. Charoenthongtrakul S, Zhou Q, Shembade N, Harhaj NS, Harhaj EW. 2011. Human T cell leukemia virus type 1 Tax inhibits innate antiviral signaling via NF-кB-dependent induction of SOCS1. J Virol 85:69556962. http://dx.doi.org/10.1128/JVI.00007-11.

24. Kashanchi F, Brady JN. 2005. Transcriptional and posttranscriptional gene regulation of HTLV-1. Oncogene 24:5938-5951. http://dx.doi.org /10.1038/si.onc.1208973.

25. Grassmann R, Aboud M, Jeang KT. 2005. Molecular mechanisms of cellular transformation by HTLV-1 Tax. Oncogene 24:5976-5985. http: //dx.doi.org/10.1038/sj.onc.1208978.

26. Boxus M, Twizere JC, Legros S, Dewulf JF, Kettmann R, Willems L. 2008. The HTLV-1 Tax interactome. Retrovirology 5:76. http://dx.doi.org /10.1186/1742-4690-5-76.

27. Zhao LJ, Giam CZ. 1992. Human T-cell lymphotropic virus type I (HTLV-I) transcriptional activator, Tax, enhances CREB binding to HTLV-I 21-base-pair repeats by protein-protein interaction. Proc Natl Acad Sci U S A 89:7070-7074. http://dx.doi.org/10.1073/pnas.89.15.7070.

28. Semmes OJ, Jeang KT. 1995. Definition of a minimal activation domain in human T-cell leukemia virus type I Tax. J Virol 69:1827-1833.

29. Ching YP, Chun AC, Chin KT, Zhang ZQ, Jeang KT, Jin DY. 2004. Specific TATAA and bZIP requirements suggest that HTLV-I Tax has transcriptional activity subsequent to the assembly of an initiation complex. Retrovirology 1:18. http://dx.doi.org/10.1186/1742-4690-1-18.

30. Siu YT, Chin KT, Siu KL, Choy EYW, Jeang KT, Jin DY. 2006. TORC1 and TORC2 coactivators are required for Tax activation of the human T-cell leukemia virus type 1 long terminal repeats. J Virol 80:7052-7059. http://dx.doi.org/10.1128/JVI.00103-06.

31. Ballard DW, Böhnlein E, Lowenthal JW, Wano Y, Franza BR, Greene WC. 1988. HTLV-I Tax induces cellular proteins that activate the $\kappa B$ element in the IL-2 receptor $\alpha$ gene. Science 241:1652-1655. http://dx.doi .org/10.1126/science.2843985.

32. Leung K, Nabel GJ. 1988. HTLV-1 transactivator induces interleukin-2 receptor expression through an NF- $\kappa B-l i k e$ factor. Nature 333:776-778. http://dx.doi.org/10.1038/333776a0.

33. Ruben S, Poteat H, Tan TH, Kawakami K, Roeder R, Haseltine W, Rosen CA. 1988. Cellular transcription factors and regulation of IL-2 receptor gene expression by HTLV-I Tax gene product. Science 241:8992. http://dx.doi.org/10.1126/science.2838905.

34. Chan JK, Greene WC. 2012. Dynamic roles for NF-кB in HTLV-I and HIV-1 retroviral pathogenesis. Immunol Rev 246:286-310. http://dx.doi .org/10.1111/j.1600-065X.2012.01094.x.

35. Hyun J, Ramos JC, Toomey N, Balachandran S, Lavorgna A, Harhaj E, Barber GN. 2015. Oncogenic human T-cell lymphotropic virus type 1 Tax suppression of primary innate immune signaling pathways. J Virol 89: 4880-4893. http://dx.doi.org/10.1128/JVI.02493-14.

36. Suzuki S, Zhou Y, Refaat A, Takasaki I, Koizumi K, Yamaoka S, Tabuchi Y, Saiki I, Sakurai H. 2010. Human T cell lymphotropic virus 1 manipulates interferon regulatory signals by controlling the TAK1-IRF3 and IRF4 pathways. J Biol Chem 285:4441-4446. http://dx.doi.org/10 $.1074 /$ jbc.M109.031476.

37. Diani E, Avesani F, Bergamo E, Cremonese G, Bertazzoni U, Romanelli MG. 2015. HTLV-1 Tax protein recruitment into IKKe and TBK1 kinase complexes enhances IFN-I expression. Virology 476:92-99. http://dx.doi .org/10.1016/j.virol.2014.12.005.

38. Chan CP, Siu YT, Kok KH, Ching YP, Tang HMV, Jin DY. 2013. Group I p21-activated kinases facilitate Tax-mediated transcriptional activation 
of the human T-cell leukemia virus type 1 long terminal repeats. Retrovirology 10:47. http://dx.doi.org/10.1186/1742-4690-10-47.

39. Tang HMV, Gao WW, Chan CP, Siu YT, Wong CM, Kok KH, Ching YP, Takemori H, Jin DY. 2013. LKB1 tumor suppressor and saltinducible kinases negatively regulate human T-cell leukemia virus type 1 transcription. Retrovirology 10:40. http://dx.doi.org/10.1186/1742-4690 $-10-40$.

40. Kew C, Lui PY, Chan CP, Liu X, Au SWN, Mohr I, Jin DY, Kok KH. 2013. Suppression of PACT-induced type I interferon production by herpes simplex virus 1 Us11 protein. J Virol 87:13141-13149. http://dx.doi .org/10.1128/JVI.02564-13.

41. Tang HMV, Gao WW, Chan CP, Cheng Y, Chaudhary V, Deng JJ, Yuen KS, Wong CM, Ng IOL, Kok KH, Zhou J, Jin DY. 2014. Requirement of CRTC1 coactivator for hepatitis B virus transcription. Nucleic Acids Res 42:12455-12468. http://dx.doi.org/10.1093/nar/gku925.

42. Siu KL, Kok KH, Ng MHJ, Poon VKM, Yuen KY, Zheng BJ, Jin DY. 2009. Severe acute respiratory syndrome coronavirus M protein inhibits type I interferon production by impeding the formation of TRAF3·TANK·TBK1/IKKe complex. J Biol Chem 284:16202-16209. http: //dx.doi.org/10.1074/jbc.M109.008227.

43. Siu KL, Chan CP, Woo PCY, Jin DY. 2014. Comparative analysis of the activation of unfolded protein response by spike proteins of severe acute respiratory syndrome coronavirus and human coronavirus HKU1. Cell Biosci 4:3. http://dx.doi.org/10.1186/2045-3701-4-3.

44. Siu KL, Chan CP, Kok KH, Woo PCY, Jin DY. 2014. Suppression of innate antiviral response by severe acute respiratory syndrome coronavirus $\mathrm{M}$ protein is mediated through the first transmembrane domain. Cell Mol Immunol 11:141-149. http://dx.doi.org/10.1038/cmi.2013.61.

45. Zhu FX, King SM, Smith EJ, Levy DE, Yuan Y. 2002. A Kaposi's sarcoma-associated herpesviral protein inhibits virus-mediated induction of type I interferon by blocking IRF-7 phosphorylation and nuclear accumulation. Proc Natl Acad Sci U S A 99:5573-5578. http://dx.doi.org/10 $.1073 /$ pnas.082420599.

46. Jin DY, Spencer F, Jeang KT. 1998. Human T-cell leukemia virus type I oncoprotein Tax targets the human mitotic checkpoint protein MAD1. Cell 93:81-91. http://dx.doi.org/10.1016/S0092-8674(00)81148-4.

47. Jin DY, Giordano V, Kibler KV, Nakano H, Jeang KT. 1999. Role of adapter function in oncoprotein-mediated activation of NF-кB: human T-cell leukemia virus type I Tax interacts directly with ІкB kinase $\gamma$. J Biol Chem 274:17402-17405.

48. Siu YT, Ching YP, Jin DY. 2008. Activation of TORC1 transcriptional coactivator through MEKK1-induced phosphorylation. Mol Biol Cell 19: 4750-4761. http://dx.doi.org/10.1091/mbc.E08-04-0369.

49. Strahle L, Garcin D, Kolakofsky D. 2006. Sendai virus defectiveinterfering genomes and the activation of interferon- $\beta$. Virology 351:101111. http://dx.doi.org/10.1016/j.virol.2006.03.022.

50. Ho TH, Kew C, Lui PY, Chan CP, Satoh T, Akira S, Jin DY, Kok KH. 2016. PACT- and RIG-I-dependent activation of type I interferon production by a defective-interfering RNA in measles virus vaccine. J Virol 90: 1557-1568. http://dx.doi.org/10.1128/JVI.02161-15.

51. Igakura T, Stinchcombe JC, Goon PK, Taylor GP, Weber JN, Griffiths GM, Tanaka Y, Osame M, Bangham CR. 2003. Spread of HTLV-I between lymphocytes by virus-induced polarization of the cytoskeleton. Science 299:1713-1716. http://dx.doi.org/10.1126/science.1080115.

52. Sharma S, tenOever BR, Grandvaux N, Zhou GP, Lin R, Hiscott J. 2003. Triggering the interferon antiviral response through an IKK-related pathway. Science 300:1148-1151. http://dx.doi.org/10.1126/science.1081315.

53. McWhirter SM, Fitzgerald KA, Rosains J, Rowe DC, Golenbock DT,
Maniatis T. 2004. IFN-regulatory factor 3-dependent gene expression is defective in Tbk1-deficient mouse embryonic fibroblasts. Proc Natl Acad Sci U S A 101:233-238. http://dx.doi.org/10.1073/pnas.2237236100.

54. Zhong B, Yang Y, Li S, Wang YY, Li Y, Diao F, Lei C, He X, Zhang L, Tien P, Shu HB. 2008. The adaptor protein MITA links virus-sensing receptors to IRF3 transcription factor activation. Immunity 29:538-550. http://dx.doi.org/10.1016/j.immuni.2008.09.003.

55. Liu S, Cai X, Wu J, Cong Q, Chen X, Li T, Du F, Ren J, Wu YT, Grishin NV, Chen ZJ. 2015. Phosphorylation of innate immune adaptor proteins MAVS, STING, and TRIF induces IRF3 activation. Science 347:aaa2630. http://dx.doi.org/10.1126/science.aaa2630.

56. Lin R, Heylbroeck C, Pitha PM, Hiscott J. 1998. Virus-dependent phosphorylation of the IRF-3 transcription factor regulates nuclear translocation, transactivation potential, and proteasome-mediated degradation. Mol Cell Biol 18:2986-2996. http://dx.doi.org/10.1128/MCB.18.5 .2986.

57. Smith MR, Greene WC. 1990. Identification of HTLV-I Tax transactivator mutants exhibiting novel transcriptional phenotypes. Genes Dev 4:1875-1885. http://dx.doi.org/10.1101/gad.4.11.1875.

58. Semmes OJ, Jeang KT. 1992. Mutational analysis of human T-cell leukemia virus type I Tax: regions necessary for function determined with 47 mutant proteins. J Virol 66:7183-7192.

59. Pomerantz JL, Baltimore D. 1999. NF- $\mathrm{\kappa B}$ activation by a signaling complex containing TRAF2, TANK and TBK1, a novel IKK-related kinase. EMBO J 18:6694-6704. http://dx.doi.org/10.1093/emboj/18.23.6694.

60. Fitzgerald KA, McWhirter SM, Faia KL, Rowe DC, Latz E, Golenbock DT, Coyle AJ, Liao SM, Maniatis T. 2003. IKKe and TBK1 are essential components of the IRF3 signaling pathway. Nat Immunol 4:491-496. http://dx.doi.org/10.1038/ni921

61. Au WC, Moore PA, Lowther W, Juang YT, Pitha PM. 1995. Identification of a member of the interferon regulatory factor family that binds to the interferon-stimulated response element and activates expression of interferon-induced genes. Proc Natl Acad Sci U S A 92:11657-11661. http: //dx.doi.org/10.1073/pnas.92.25.11657.

62. Sze A, Belgnaoui SM, Olagnier D, Lin R, Hiscott J, van Grevenynghe J. 2013. Host restriction factor SAMHD1 limits human T cell leukemia virus type 1 infection of monocytes via STING-mediated apoptosis. Cell Host Microbe 14:422-434. http://dx.doi.org/10.1016/j.chom.2013.09.009.

63. Chu ZL, Shin YA, Yang JM, DiDonato JA, Ballard DW. 1999. IKKy mediates the interaction of cellular ІкВ kinases with the tax transforming protein of human T cell leukemia virus type 1. J Biol Chem 274:1529715300. http://dx.doi.org/10.1074/jbc.274.22.15297.

64. Harhaj EW, Sun SC. 1999. IKK $\gamma$ serves as a docking subunit of the IкB kinase (IKK) and mediates interaction of IKK with the human T-cell leukemia virus Tax protein. J Biol Chem 274:22911-22914. http://dx.doi.org /10.1074/jbc.274.33.22911.

65. Chiang C, Beljanski V, Yin K, Olagnier D, Ben Yebdri F, Steel C, Goulet ML, DeFilippis VR, Streblow DN, Haddad EK, Trautmann L, Ross T, Lin R, Hiscott J. 2015. Sequence-specific modifications enhance the broad-spectrum antiviral response activated by RIG-I agonists. J Virol 89:8011-8025. http://dx.doi.org/10.1128/JVI.00845-15.

66. Sali TM, Pryke KM, Abraham J, Liu A, Archer I, Broeckel R, Staverosky JA, Smith JL, Al-Shammari A, Amsler L, Sheridan K, Nilsen A, Streblow DN, DeFilippis VR. 2015. Characterization of a novel human-specific STING agonist that elicits antiviral activity against emerging alphaviruses. PLoS Pathog 11:e1005324. http://dx .doi.org/10.1371/journal.ppat.1005324. 